\title{
A RECONSTRUCTION OF MIDDLE HOLOCENE ALLUVIAL HARDWOOD FORESTS (LOWER SCHELDT RIVER, NORTHERN BELGIUM) AND THEIR EXPLOITATION DURING THE MESOLITHIC-NEOLITHIC TRANSITION PERIOD (SWIFTERBANT CULTURE, CA. 4,500 - 4,000 BC)
}

\author{
Koen DEFORCE ${ }^{* 1,2,3}$, Jan BASTIAENS ${ }^{1} \&$ Philippe CROMBÉ ${ }^{3}$
}

\begin{abstract}
The analysis of a large number of charcoal fragments from fire places from a wetland camp site of the Mesolithic-Neolithic transition period (Swifterbant culture) now permits a detailed reconstruction of a middle Holocene riverine forest along the Lower Scheldt River (northern Belgium) and its exploitation between ca. 4,500 and 4,000 BC. The identified taxa point towards an alluvial hardwood forest (Querco-Ulmetum minoris Issler 1924) on the sand dune on which the camp site was situated, surrounded by alder carr. The results are compared with palynological and macrobotanical analyses from the same site and from contemporary sites within the area; the complementarity of these different types of data is discussed. The combination of all these datasets results in a detailed reconstruction of the environment and of its exploitation by the Swifterbant culture. The results also show that the Swifterbant people not only depended on these sand ridges for dry settlement locations, but also for firewood collection, gathering of edible plants and most probably for the collection of leaf fodder to feed livestock during winter time.
\end{abstract}

Keywords: alluvial hardwood forest, charcoal analysis, woodland exploitation, vegetation reconstruction, Swifterbant culture

\section{RÉSUMÉ}

RECONSTITUTION DES FORÊTS ALLUVIALES DE BOIS DUR À L'HOLOCĖNE MOYEN (BASSE VALLÉE DE L'ESCAUT, NORD DE LA BELGIQUE) ET LEUR EXPLOITATION PENDANT LA TRANSITION MÉSOLITHIQUE-NÉOLITHIQUE (CULTURE SWIFTERBANT, CA. 4 500-4 000 AV. J.-C.)

L'analyse d'un grand nombre de charbons de bois provenant des foyers d'un site palustre daté de la période de transition Mésolithique-Néolithique (culture Swifterbant) a permis une reconstitution détaillée d'une forêt riveraine le long de l'Escaut au cours de l'Holocène moyen et de son exploitation entre ca. 4500 et 4000 av. J.-C. Les taxons identifiés indiquent la présence d'une forêt alluviale de bois dur (Querco-Ulmetum minoris Issler 1924) développée sur la dune sableuse sur laquelle le campement se situait, et qui était entourée par une aulnaie. Les résultats anthracologiques sont comparés avec ceux des analyses palynologiques et carpologiques obtenus sur ce même site, mais aussi avec ceux d'autres sites contemporains de la région; la complémentarité de ces différents types de données est discutée. La combinaison de l'ensemble des informations conduit à une reconstitution détaillée du paléoenvironnement et de son exploitation par la culture Swifterbant. Les résultats montrent également que les dunes sableuses ne sont pas uniquement des sites préférentiels pour l'installation des campements mais que ces environnements revêtaient aussi une grande importance pour la collecte de bois de feu, de plantes comestibles ou encore très probablement pour la collecte de fourrage pour nourrir le bétail en hiver.

Mots-clés : forêt alluviale de bois dur, anthracologie, exploitation forestière, reconstitution de la végétation, culture Swifterbant

\section{1 - INTRODUCTION}

During the middle and most of the late Holocene period, the southern North Sea coast stretching from northwestern Belgium to Lower Saxony (Germany) formed a vast area of wetlands, consisting of coastal marshes, fens, bogs and large areas of riverine and estuarine wetlands along the lower courses of Scheldt, Meuse, Rhine and
Ems rivers (Pons, 1992; Vos \& Van Heeringen, 1997; Behre, 2004; Vos et al., 2011). Between ca. 5,000 and ca. $3,400 \mathrm{BC}$, these wetlands were inhabited by people belonging to the Swifterbant culture and Hazendonk group (further referred to as Swifterbant culture) and which represents the transition of a (Mesolithic) hunter-gatherer to an (Neolithic) agro-pastoral subsistence system for this region (Louwe Kooijmans, 2007a). This culture was

\footnotetext{
${ }^{1}$ Flanders Heritage, Koning Albert II-laan 19, bus 5, BE-1210 BRUSSELS. Tel.: ++32 255318 35. Fax: ++32 25531655.

Emails: koen.deforce@rwo.vlaanderen.be, jan.bastiaens@rwo.vlaanderen.be

${ }^{2}$ Royal Belgian Institute of Natural Sciences, Vautierstraat 29, BE-1000 BRUSSELS

${ }^{3}$ Ghent University, Department of Archaeology, Sint-Pietersnieuwstraat 35, BE-9000 GENT. Email: philippe.crombe@ugent.be

* Corresponding author
} 
characterized by a broad spectrum economy, exploiting a wide variety of resources from different environments within the landscape (Louwe Kooijmans, 1993; 2007b). Even after the gradual adoption of first domestic animals and later cultivated plants, hunting, gathering, fowling and fishing remained important elements in Swifterbant economy. Therefore, data on the environmental context of Swifterbant sites are crucial for the understanding of this culture and the way it made the transition from a Mesolithic to a Neolithic economy.

Apart for some rare exceptions (e.g. Deichmüller, 1965; Out, 2012), almost all of the known Swifterbant sites are situated on sand ridges, dunes and levees that represented the only relatively permanent dry areas within these vast wetlands (Van Der Woude, 1983; Louwe Kooijmans, 1987; Dresscher \& Raemaekers, 2001; Mol, 2003; Kooijmans, 2009). Most palaeoenvironmental data for this region however are derived from pollen sequences, basically reflecting the regional dominant wetland vegetation (e.g. Casparie et al., 1977; Van der Wiel, 1982; Van der Woude, 1983; Bakels \& Van Beurden, 2001; Gelorini, 2006; Out, 2008, 2010a; Deforce, 2011). Also macrobotanical studies from waterlogged sediments provide little information on the "dryland" vegetation that must have covered the dunes on which the sites are situated (e.g. Van der Wiel, 1982; Out, 2008). Moreover, the analyzed sediments in the vicinity of these sites, which are contemporaneous to the occupation period, are often alluvial (peaty) clay and it is therefore not always possible to tell if the plant remains are of local origin or have been transported to the site from elsewhere by river water (Schepers et al., 2013).

Some information is provided by seeds and fruits from anthropogenic structures and refuse layers, but the assemblages from these features can be expected to be biased by selection in favor of edible and other useful plants (e.g. Bakels \& Van Beurden, 2001; Bastiaens et al., 2005; Out, 2010a, 2012). Also the assemblages of worked wood from these sites are likely to be biased by selection (e.g. Casparie et al., 1977).

As the collection of firewood in Mesolithic and Neolithic economies is generally believed to be based on "the principle of least effort" (Shackleton \& Prins, 1992), the analysis of charcoal from archaeological features from these sites might therefore be a more useful tool for the reconstruction of the local (woody) vegetation. An overview of charcoal data from Swifterbant sites is given by Out (2010b). Unfortunately the data are, except for the site of Hoge Vaart - A27 (Van Rijn \& Kooistra, 2001), based on only a limited number of identifications. As a consequence, information about the composition of the local vegetation on the sand dunes and levees where these sites are located is still restricted.

The analysis of a large number of charcoal fragments from the remains of surface hearths of a Swifterbant camp site near Doel (NW Belgium) (fig. 1), which was occupied between ca. 4,500 and 4,000 BC, now permits a detailed reconstruction of the woody vegetation in one of these specific environments. These results are combined with charcoal and other macrobotanical analyses from the same and contemporary sites within the same area, and with off-site palynological analyses. This not only provides additional information on the environment of the Swifterbant people, but also on the way this specific environment was exploited by this cultural group.

\section{2 - THE SITE}

\section{1 - REGIONAL SETTING}

Salvage excavations preceding the construction of the "Deurganck dock" as part of the harbour of Antwerp, on the left bank of the Scheldt River, revealed three Swifterbant sites (sector B, J/L and M; fig. 1) (northern Belgium; $51^{\circ} 17^{\prime} \mathrm{N}, 4^{\circ} 15^{\prime}$ E) (Crombé et al., 2004, 2009). These sites are situated on top of late Pleistocene aeolian coversand ridges at a mean depth of 0.5 to $1.0 \mathrm{~m}$ below the actual sea level. They are characterized by large clusters of pottery fragments and lithic artifacts and, at sector B and $\mathrm{M}$, also smaller clusters $(<1 \mathrm{~m})$ of burnt plant remains and burnt bone occurred. The latter are interpreted as the remains of surface hearths and/or hearth dumps (Crombé et al., 2004, 2009). Based on previous research, these sites are believed to be temporary hunting and fishing camps, at which also livestock was held (Crombé, 2005; Deforce et al., 2013; Van Neer et al., 2013). No evidence has been found for local crop cultivation (Bastiaens et al., 2005; Deforce et al., 2013).

The sand ridges on which the sites were situated are narrow, ca. 30-40 m wide, and generally show a N(W)$\mathrm{S}(\mathrm{E})$ orientation. During the mid-Holocene period these ridges formed the highest places in the topography of the broad palaeo-valley of the lower Scheldt River. They were probably one of the few dry places as extensive wetlands dominated by Alnus woodland (and associated peat growth) developed in the Lower Scheldt valley from at least ca. 5,690 $\mathrm{BC}$ as a consequence of post glacial relative sea level rise (Vos \& Van Heeringen, 1997; Deforce, 2011). This peat growth was interrupted between ca. 4,600 and 3,700 BC by the deposition of estuarine (peaty) clay (Deforce, 2011).

\section{2 - LOCAL STRATIGRAPHY AND CHRONOLOGY}

At Doel, alder carr developed and wood peat accumulation started in the depressions between the sand ridges from ca. 4,760 BC onwards (fig. 2) (Van Strydonck \& Crombé, 2005; Gelorini et al., 2006). Peat growth was interrupted between ca. 4,590 and ca. 3,730 BC by the deposition of peaty clay. After ca. 3,730 BC, peat accumulation resumed (and covered the sand ridges), first in an eutrophic alder carr environment, later a mesotrophic sedge fen and birch carr and finally a raised bog. This upper peat layer was covered by marine clayey sediments from 680 AD onwards (Van Strydonck \& Crombé, 2005; Gelorini et al., 2006).

In the top layer of the sand ridge, a brunified soil is present, which is covered by wood peat. An eluviated E horizon is absent in the soil profile. The buried surface 


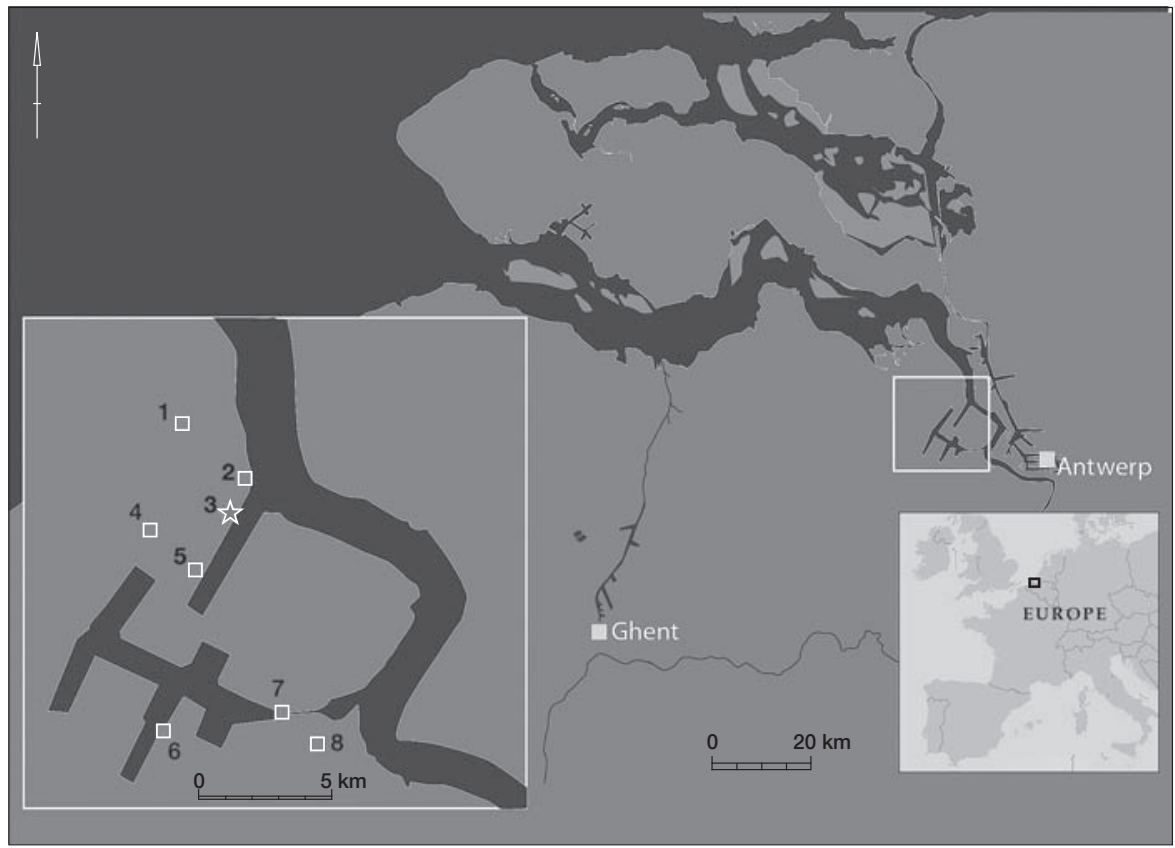

Fig. 1: Location of the studied site (3) and of other sites mentioned in the text.

1/ Doel NPP (Deforce, 2011), 2/ Doel sector A (Gelorini et al., 2006), 3/ Doel sector B (this publication), 4/ Doeldok (Minnaert \& Verbruggen, 1986), 5/ Doel sector M (Deforce et al., 2013), 6/ Kallo-Vrasenedok (Janssens \& Fergusson, 1985), 7/ Kallo - Zeesluis (Kuijper, 2006), 8/ Hof ten Damme (Verbruggen \& Denys, 1995).

Fig. 1 : Localisation du site étudié (3) et des autres sites mentionnés dans le texte. 1/Doel NPP (Deforce, 2011), 2/ Doel secteur A (Gelorini et al., 2006), 3/ Doel secteur B (cette étude), 4/ Doeldok (Minnaert \& Verbruggen, 1986), 5/ Doel secteur M (Deforce et al., 2013), 6/ Kallo - Vrasenedok (Janssens \& Fergusson, 1985), 7/ Kallo - Zeesluis (Kuijper, 2006), 8/ Hof ten Damme (Verbruggen \& Denys, 1995).

A horizon (H2) of this soil profile has a higher clay and silt content than the underlying horizons (Louwagie \& Langohr, 2005), and is considered to be the Swifterbant occupation surface.

\section{3 - PREVIOUS RESEARCH}

A description of the site Doel sector B and the excavated features is given by Crombé (2005). A first assessment of the wood charcoal macro-remains of Doel sector B (Klinck, 2005) resulted in the identification of a small number of fragments and a limited number of identified taxa. The study of the wood charcoal from the neighboring and contemporary site of Doel sector M (Deforce et al., 2013) showed the importance however of these collections and it was decided to conduct a full analysis of the charcoal fragments from sector B as well. The results of the analysis of charred seeds and fruits from Doel sector B have been published by Bastiaens et al. (2005) and the zoological remains (including a large number of fish bones) of both sites have been published by Van Neer et al. (2005) and Van Neer et al. (2013). Off-site pollen data from contemporaneous peat/peaty clay deposits are available for Doel sector A (Gelorini et al., 2006), DoelNPP (Deforce, 2011), Doeldok (Minnaert \& Verbruggen, 1986), Kallo-Vrasenedok (Janssens \& Fergusson, 1985) and Kallo-Zeesluis (Kuijper, 2006) (fig. 1).

This paper now presents the results of new charcoal identifications from Doel sector B, but for the interpretation and discussion, these results are combined with the data from the above mentioned published analyses from contemporaneous sites within the study area.

\section{3 - MATERIAL AND METHODS}

Three different zones on top of the sand ridge within sector B have been excavated. The layer containing artefacts and charred botanical and zoological remains was entirely sampled following a grid of $0.5 \mathrm{~m} \times 0.5 \mathrm{~m}$ and sieved in the field, except for 3 liters subsamples for the analyses of charcoal and other botanical macro-remains that were wet sieved in the lab using tap water and a mesh size of $0.5 \mathrm{~mm}$.

A total of 19 samples from 5 surface hearths have been analyzed. The residues were randomly sampled for charcoal fragments, disregarding the dimensions of the individual fragments. From each sample, a minimum of 200 fragments has been studied whenever possible, otherwise all charcoal fragments from the sample have been analyzed. Samples producing less than 50 potentially identifiable charcoal fragments have not been analyzed. For identification, each fragment was broken manually and the anatomical characteristics were observed in transverse, tangential and radial planes, using a reflected light microscope (Olympus BX41) with dark field illumination and magnifications up to 500x. In some cases, i.e. when not all diagnostic anatomical characteristics were visible, the charcoal fragments were studied using a desktop SEM (Phenom G2 Pure). Identification is based on wood anatomical identification keys and atlases (Schweingruber, 1990; Grosser, 2003; Schoch et al., 2004), and a reference collection of charred modern wood specimens.

For samples that had previously been analysed by Klink (2005) all identifications of charcoal fragments have been revised. 


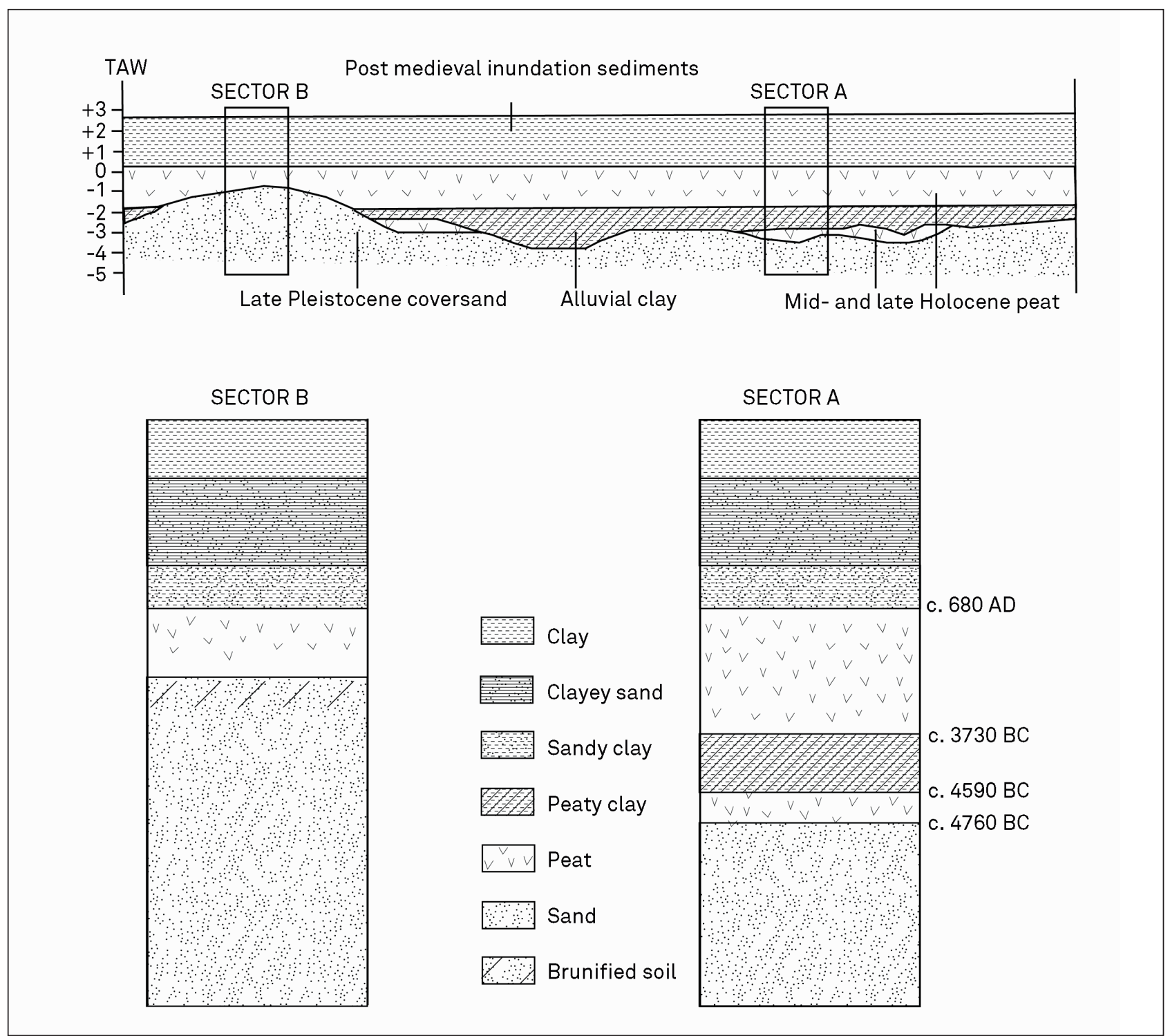

Fig. 2: Schematical drawing of the profiles (after Crombé, 2005).

Radiocarbon dates from Van Stydonck and Crombé (2005). (TAW: The Belgian ordnance datum that refers to mean lowest water spring and corresponding to ca. $2 \mathrm{~m}$ below mean sea level).

Fig. 2 : Représentation schématique des profils (d'après Crombé, 2005). Dates radiocarbone d'après Van Stydonck et Crombé (2005). (TAW : Niveau de référence d'altitude belge, correspondant au niveau d'eau moyen le plus bas, soit environ $2 \mathrm{~m}$ sous le niveau de la mer).

Eight identified charred seeds or charcoal fragments from the different surface hearths have been AMS radiocarbon dated. Calibration was done with Oxcal 4.2 (Bronk Ramsey, 2009) using atmospheric data from Reimer et al. (2009).

\section{4 - RESULTS AND DISCUSSION}

\section{1 - RADIOCARBON DATES}

The results of the radiocarbon dates are presented in table 1 and figure 3 (after Van Strydonck \& Crombé, 2005). The sum of all dates falls in a range between 4,500 and $3,990 \mathrm{BC}$ (95\% probability range) or 4,435 and 4,334 $\mathrm{BC}$ (interquartile range) and contains no real outliers. The three northernmost surface-hearths (SH1, $\mathrm{SH} 2$ and $\mathrm{SH} 3$ ) show a very similar age distribution.
SH4 and SH5, which are situated more southwards and higher up the top of the sand dune, gave slightly younger dates.

All dates fit within the time frame of the middle phase of the Swifterbant culture, dated in the area south of the Rhine-Meuse between ca. 4,600 and 3,900 BC (Raemaekers \& de Roever, 2010; Crombé et al., 2011). This also corresponds well with the characteristics of both the lithic and the ceramic artifacts found at the site (Crombé, 2005; Crombé et al., 2011). These dates also show that the occupation of the site was broadly contemporaneous with sector $\mathrm{M}$, which produced dates between 4,575 and 4,038 BC (sum of all dates, $95 \%$ probability range) (Deforce et al., 2013), though the interquartile range of the radiocarbon dates of sector $\mathrm{M}(4,368$ - 4,156 BC) (Deforce et al., 2013) indicates that the main occupation is slightly younger than at Doel sector B (ca. 4,435 and 4,334 BC). These age distributions also show that 


\begin{tabular}{|c|c|c|c|c|c|c|c|}
\hline $\begin{array}{l}\text { Sample } \\
\text { code }\end{array}$ & Feature & Sample type & $\begin{array}{l}\text { Sample } \\
\text { identification }\end{array}$ & Lab no. & $\begin{array}{l}\delta^{13} \\
\mathrm{C} \% 0 \\
\end{array}$ & Age (uncal BP) & 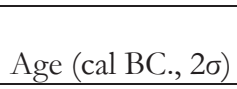 \\
\hline W16/Z7(1) & SH1 & charcoal & Maloideae & KIA-17995 & -25.3 & $5635 \pm 30$ & $4539-4369$ \\
\hline W19/Z1(4) & $\mathrm{SH} 2$ & charcoal & Quercus sp. & KIA-17996 & -26.3 & $5595 \pm 35$ & $4491-4355$ \\
\hline W20/Z2(1) & $\mathrm{SH} 2$ & charcoal & Cornus sp. & KIA-17994 & -28.4 & $5575 \pm 35$ & $4463-4346$ \\
\hline W19/Z1(4) & $\mathrm{SH} 2$ & charred seeds & Hedera belix & KIA-17997 & -27.1 & $5550 \pm 35$ & $4454-4342$ \\
\hline W6/Z6(3) & $\mathrm{SH} 3$ & charred seeds & unidentified & KIA-17987 & -24.3 & $5570 \pm 30$ & $4457-4352$ \\
\hline W6/Z18(4) & SH4 & charred seed & Prunus spinosa & KIA-17986 & -25.8 & $5400 \pm 30$ & $4339-4085$ \\
\hline R069 & SH5 & charred shell & Corylus avellana & NZA-12076 & -26.4 & $5220 \pm 55$ & $4232-3951$ \\
\hline W16/Z8(1) & & charred shell & Corylus avellana & KIA-32618 & -28.29 & $5595 \pm 35$ & $4491-4355$ \\
\hline
\end{tabular}

Tab. 1: Radiocarbon dates of charred botanical remains from Doel sector $B$.

Tab. 1 : Datations radiocarbone des restes botaniques carbonisés de Doel secteur $B$

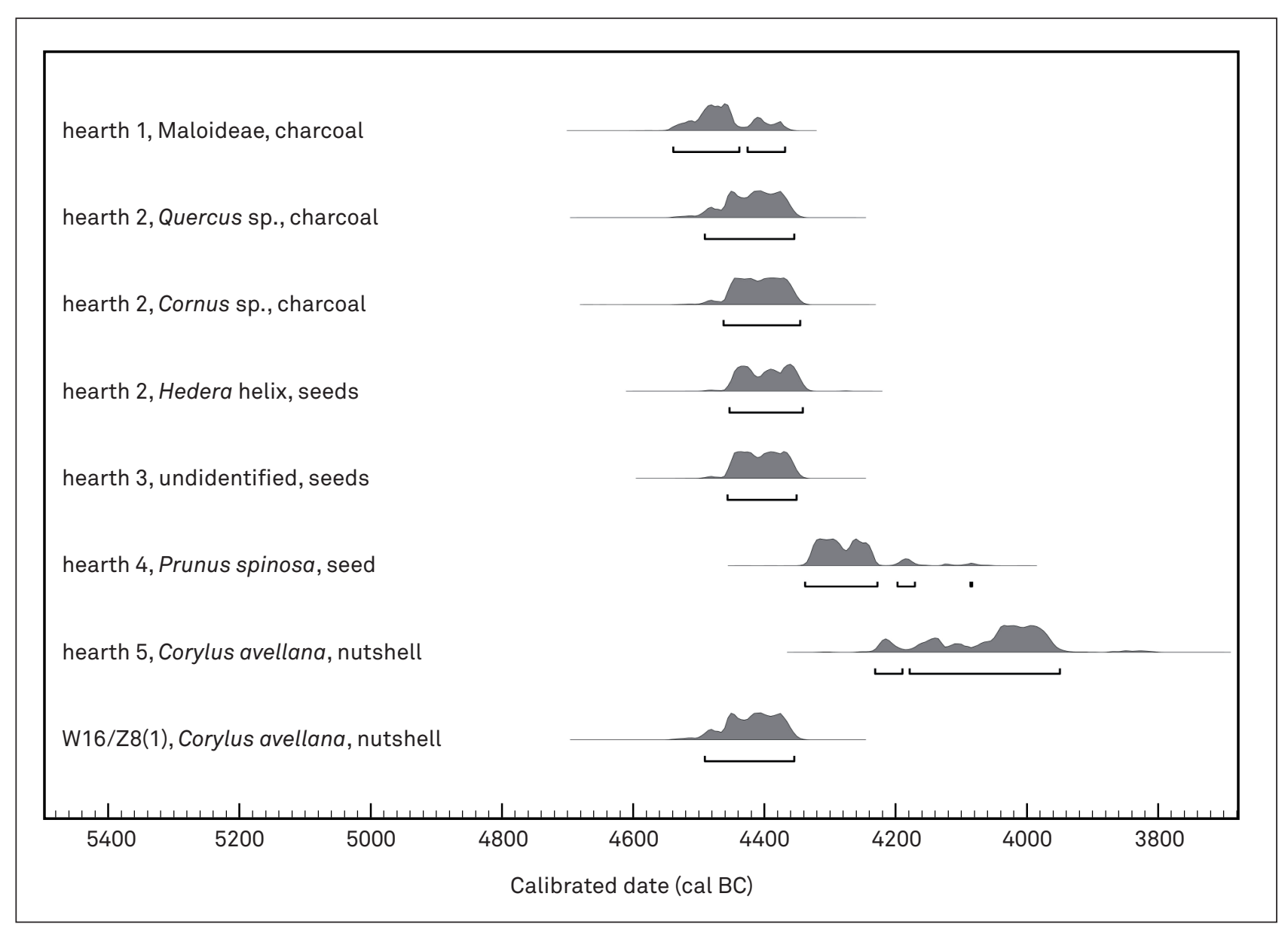

Fig. 3: Calibrated age distributions $(2 \sigma)$ from Doel sector $B$.

Fig. 3 : Distributions d'âges calibrés (2o) de Doel secteur B.

the occupation of both sector B and $\mathrm{M}$ is contemporaneous with the deposition of peaty clay in the lower areas surrounding the sand dunes on which these sites are situated (fig. 2).

\section{2 - IDENTIFIED TAXA}

The results of the charcoal identifications from Doel sector B are presented in table 2 as percentages for each analyzed quadrant, for each surface hearth and for the whole site. For each taxon, the frequency of occurrence in the analyzed samples (ubiquity) is also given. A total of
3,905 charcoal fragments have been identified belonging to 18 different taxa. Most charcoal fragments were small but well preserved. Alnus sp. and Quercus sp. are the most abundant taxa in the total charcoal assemblage. Moreover, these two taxa have been found in every analyzed sample, mostly with rather high percentages. Fraxinus excelsior, Maloideae and Corylus avallana are also important taxa in most of the analyzed samples. Cornus sp., Frangula alnus, Tilia sp., Ulmus sp., Viburnum opulus and Viscum album have not very high percentages but have been found in at least $26.3 \%$ of the samples. In some individual samples, Tilia sp. [40.3\%, sample W21 Z7(4)], 


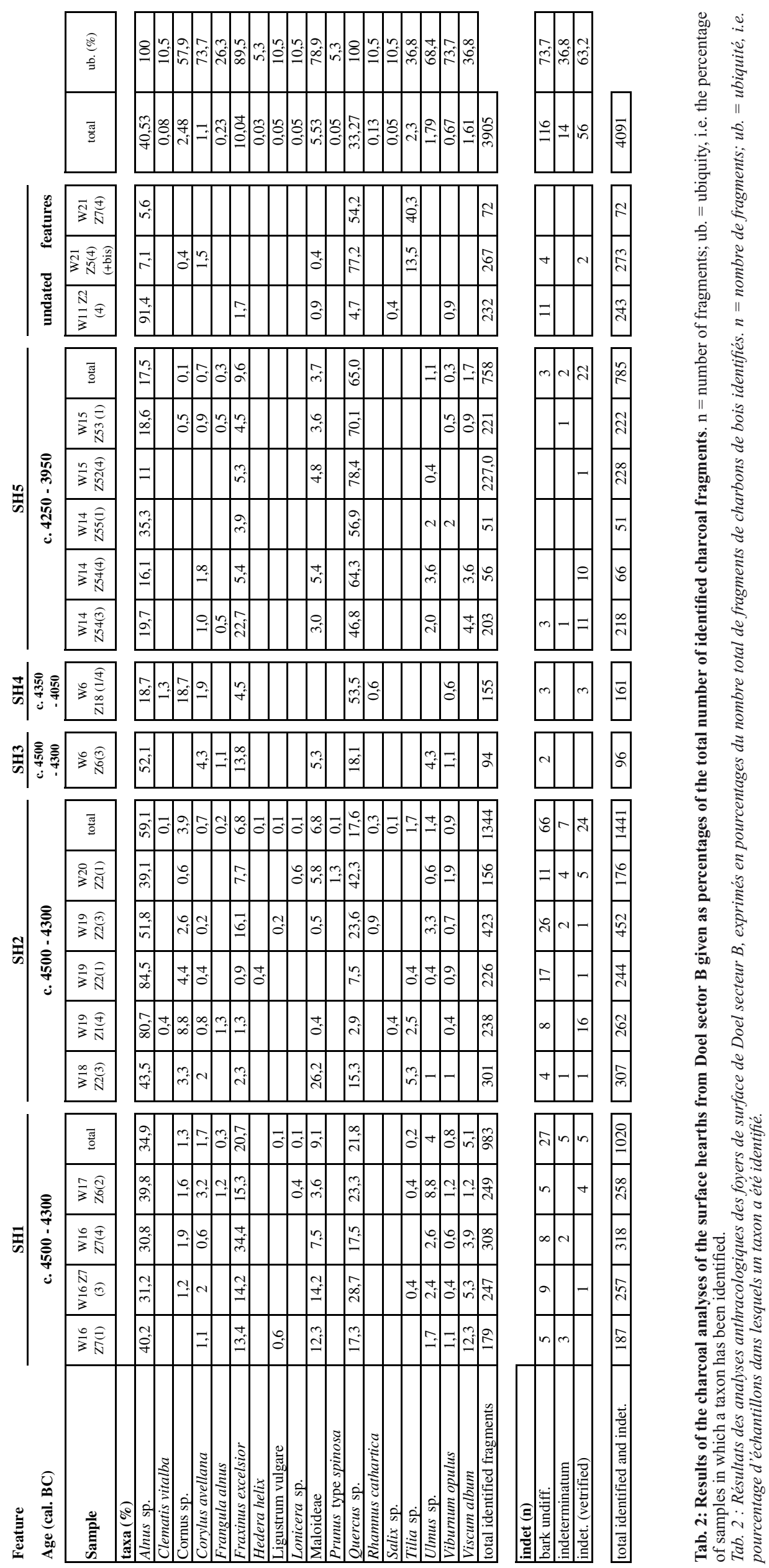


Ulmus sp. [8.8 \%, sample W17 Z6(2)] and Viscum album [12.3\%, sample W16/Z7(1)] do have rather high percentages however. Clematis vitalba, Hedera helix, Ligustrum vulgare, Lonicera sp., Prunus type spinosa, Rhamnus cathartica and Salix sp. all have very low percentages and have been found in $10.5 \%$ or less of the analyzed samples.

$1.71 \%$ of the studied charcoal fragments remained unidentified. Most of these unidentified fragments $(1.37 \%$ of all studied fragments) showed different degrees of vitrification, which obscured the anatomical characteristics and made identification impossible.

The observed charcoal assemblage is very similar to that of Doel sector M (Deforce et al., 2013). At Doel sector B, a slightly higher amount of taxa have been identified compared to sector $\mathrm{M}$ however. This can be explained by the higher total number of charcoal fragments that has been studied for sector B as only taxa found with very low percentages at sector B, i.e. Ligustrum vulgare (0.05\%), Lonicera sp. (0.05\%), Salix $(0.05 \%)$ and Rhamnus cathartica $(0.13 \%)$ have not been found at sector M. Also the additional study of previously unidentified charcoal fragments using a SEM might account for the higher taxonomic diversity at sector B.

Although charcoal identifications generally show a lower taxonomic precision compared to the identification of seeds, in Doel sector B and M, charcoal analyses produced more information on the woody vegetation than did the analyses of charred seeds (18 taxa vs. 12 taxa). Seeds of certain taxa like Clematis vitalba, Fraxinus excelsior, Salix and Ulmus have no economic use, which reduces the chance that these will get in contact with fire. And even if they would, these seeds are small and fragile and are likely to burn completely or get highly fragmented and thus become unidentifiable after carbonization.

On the other hand, the identification of charred seeds does provide additional information to the charcoal data. The wood of the two Cornus species occurring in NW Europe, i.e. C. sanguinea and C. mas, cannot be differentiated based on their anatomical characters (Schweingruber, 1990; Grosser, 2003). It is far more likely however that the charcoal found at Doel sector B can be attributed to $C$. sanguinea as $C$. mas is probably not native to NW Belgium (Maes et al., 2006). Only seeds of $C$. sanguinea have been found at Doel sector B (Bastiaens et al., 2005; fig. 4) and all other finds of both seeds and pollen of Cornus at nearby contemporary sites can be attributed to C. sanguinea (e.g. Bakels \& Van Beurden, 2001; Kuijper, 2006; Out, 2010a; Deforce, 2011; Deforce et al., 2013). The data from the study of non-wood botanical macro-remains thus allows the further interpretation of some of the charcoal identifications. This is not only the case for Cornus but the results from the analyses of the seeds also indicates that the Maloideae charcoal most probably encompass at least Crataegus monogyna and Malus sylvestris and also that both T. cordata and T. platyphyllos occurred at the site.

\section{3 - ENVIRONMENTAL RECONSTRUCTION}

As both sites of Doel sector B and M are only situated ca. $2 \mathrm{~km}$ apart, have the same position in the landscape (fig. 2), are broadly contemporaneous and produced very similar assemblages, the results of the analyses of charcoal and seeds from both sites are summarized together (fig. 4) and used for the reconstruction of the local environment. These results indicate that the vegetation on the sand ridges and their surroundings consisted of woodland composed of the trees Quercus sp., Tilia platyphyllos, $T$. cordata, Ulmus sp., Fraxinus excelsior, Alnus sp., Malus sylvestris, shrubs like Cornus sanguinea, Corylus avellana, Crataegus monogyna, Frangula alnus, Ligustrum vulgare, Prunus spinosa, Rhamnus cathartica, Salix sp., Viburnum opulus, various taxa of climbers such as Clematis vitalba, Lonicera sp. and Hedera helix and the epiphytic, hemiparasitic shrub Viscum album.

The topography of the sand dunes on which the sites of Doel sector B and M were situated, and the depressions between these, formed a gradient from rather dry to permanent wet environments at the time of their occupation. The distribution of the above mentioned taxa in the landscape will primarily have been determined by this gradient in soil wetness. Based on the ecological characters of the trees and shrubs that have been found, especially their tolerance to high groundwater levels and seasonal flooding (e.g. Ellenberg, 1988; Schnitzler 1994, 1995), the geomorphological position of the sand ridges (e.g. on the valley bottom of the lower Scheldt River), the presence of the clayey deposits surrounding the sand ridges which show a similar age as the occupation period, and the presence of a brunified soil on top of the sand ridges (Louwagie \& Langohr, 2005), a more detailed environmental reconstruction can be made however (fig 5). The local vegetation on the sand ridges must have consisted of an alluvial forest dominated by Tilia platyphyllos, T. cordata and Quercus sp. on the highest elevations and Quercus sp., Ulmus sp. and Fraxinus excelsior on the flanks. Cornus sanguinea, Corylus avellana, Crataegus monogyna, Malus sylvestris, Prunus spinosa and Ligustrum vulgare occurred in the shrub layer. The vegetation at the foot of the sand ridges and in the lowest areas surrounding these sand ridges was dominated by Alnus sp. with Rhamnus cathartica in the undergrowth. Frangula alnus and Viburnum opulus both might have occurred on slightly moist to permanent wet soils.

This corresponds with a very specific vegetation type, i.e. hardwood alluvial forests (German: HartholzAuenwald), which are phytosociologically assigned to the Alno-Ulmion and more specifically the QuercoUlmetum Issler 1924. These are considered to be one of the most productive and species-rich of temperate forest ecosystems (Carbiener, 1970; Grubb, 1987; Schnitzler, 1994). These forests occur under specific hydrodynamic conditions i.e. on areas within the river floodplain that are only incidentally touched by inundations of short duration (Schnitzler 1994; Wolf et al., 1997). The frequency of these inundations ranges from one time every few years to a few times in one year. If the frequency of 

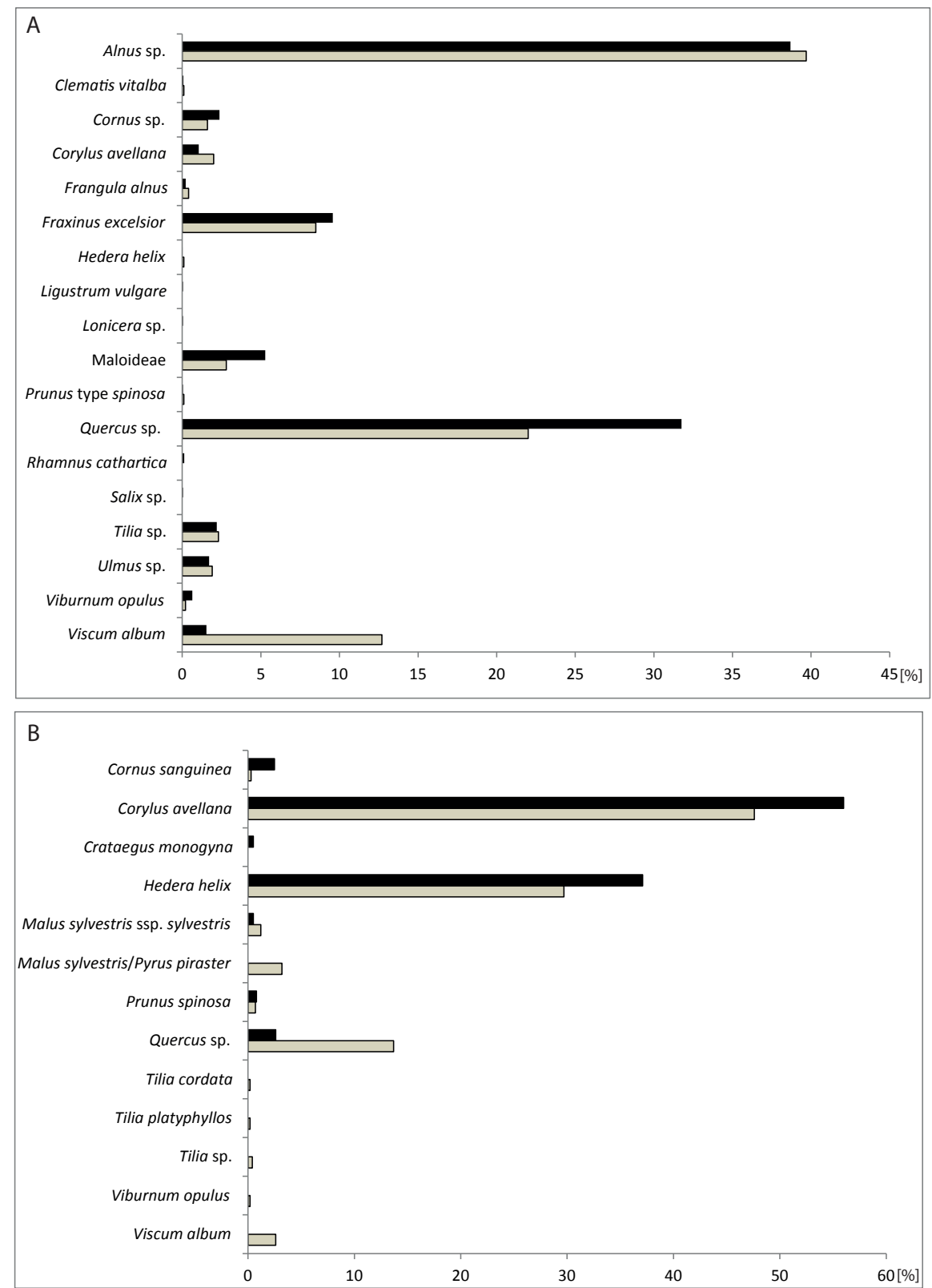

Fig. 4: A/ Charcoal assemblages from Doel sector B (black bars, data from this study) and sector M (grey bars, data from Deforce et al., 2013). B/Charred seeds (woody taxa only) from Doel sector B (black bars, data from Bastiaens et al., 2005) and sector M (grey bars, data from Deforce et al., 2013).

Fig. 4:A/Assemblages anthracologiques du secteur B (barres noires, données issues de cette étude) et du secteur M du site de Doel (barres grises, données d'après Deforce et al., 2013). B/ Graines carbonisées (uniquement de taxons ligneux) du secteur B (barres noires, données d'après Bastiaens et al., 2005) et du secteur M du site de Doel (barres grises, données d'après Deforce et al., 2013).

these inundations rises, hardwood alluvial forest will be replaced by softwood alluvial forests (German: Weichholz-Auenwald), which are characterized by Salix and Populus (Schnitzler, 1995). It is also possible that the highest places of the sand ridge, covered with the Tilia and Quercus dominated forest type, never were flooded during the time of occupation as this vegetation type also occurs outside the river valley on permanent dry soils. The high clay and silt content of the surface A horizon in the top layer of the sand ridge might be an indication that even the highest elevations of the ridge occasionally were flooded.

The high numbers of Alnus fragments in the charcoal spectra from both sector B and M show that the depressions between the sand dunes were (almost) permanent wet environments but with rather stable water levels. Also the absence of Populus and very low numbers of Salix charcoal indicate that in the immediate surroundings of the river dunes on sector $\mathrm{B}$ and $\mathrm{M}$, water levels dynamics were low and inundations were not frequent.

Alluvial environments with more frequent water level fluctuations probably only occurred at a certain distance from the site. In the pollen diagram of Doel sector A, Salix hardly occurs in the levels contemporaneous to the occupation of sector B and M (Gelorini et al., 2006). Salix does occur with higher percentages however in pollen diagrams that are situated a little further from Doel sector B, like Doel NPP (Deforce, 2011), Doel-Doeldok (Minnaert \& Verbruggen, 1986) and Kallo-Vrasenedok (Janssens \& Ferguson, 1985), At 


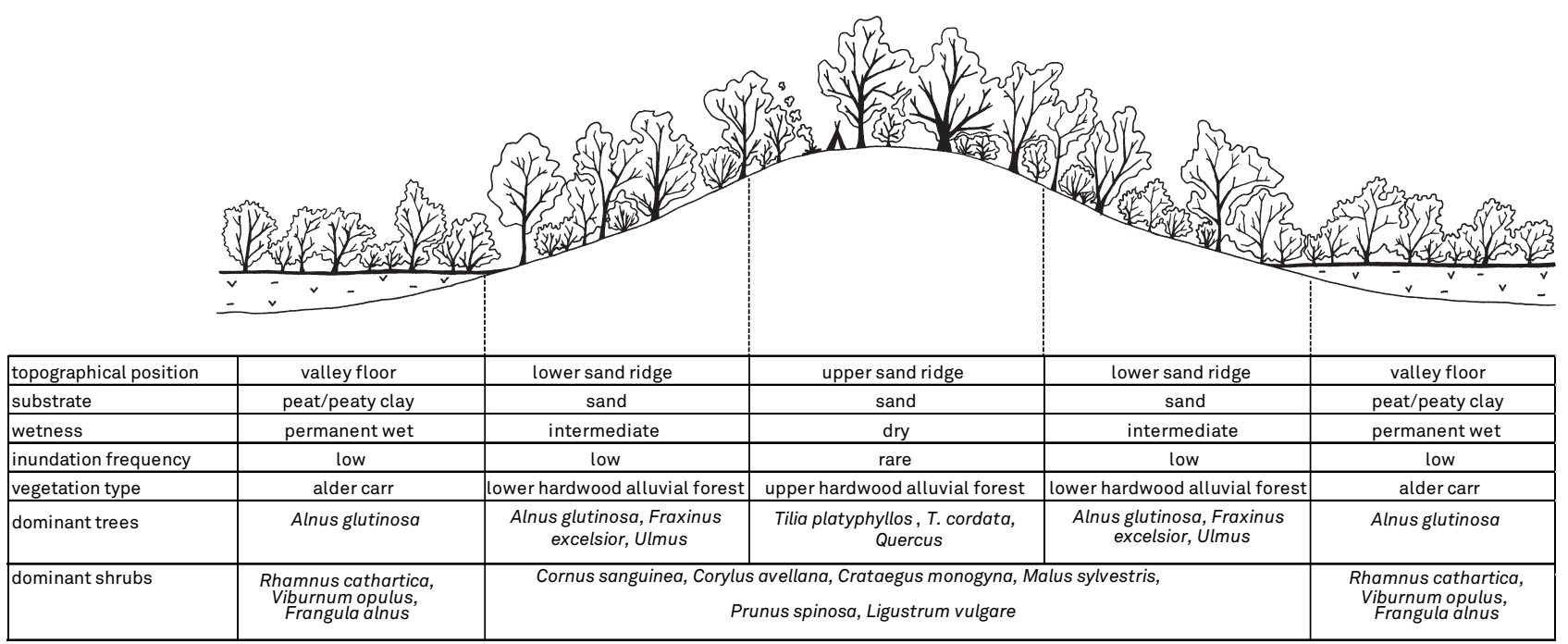

Fig. 5: Schematic reconstruction of the vegetation in relation with its topographical position and inundation frequency for the environment of Doel sector $B$ between ca. 4,500 - 4,000 BC.

Fig. 5 : Reconstitution schématique de la relation entre la position topographique, la fréquence des inondations et la couverture végétale pour l'environnement de Doel secteur B entre ca. 4500 - 4000 av. J.-C.

Kallo-Zeesluis, the occurrence of the mollusc Mercuria confusa in the deposit of a large gully, dated shortly after 4,600 BC indicates a freshwater tidal environment (Kuijper, 2006).

This environmental reconstruction is in line with the results of the analyses of burnt fish bone from both Doel sector $\mathrm{B}$ and $\mathrm{M}$. These indicate an estuarine environment of creeks with a lot of stagnant fresh water, although some other taxa are more salt tolerant and must have migrated upsteam from brackish or marine environments (Van Neer et al., 2005; Van Neer et al., 2013). A (peri-)marine influence in the area is also indicated by the sporadic occurrence of marine microfossils like Foraminifera and Dinoflagellata in the pollen diagram from Doel-NPP (Deforce, 2011), a rise in pollen percentages of the salttolerant Chenopodiaceae family in all pollen diagrams from the region (see Deforce, 2011 for a review) and the occurrence of several meso- and polyhaobous diatom taxa in the peaty clay deposit at Kallo-in Hof ten Damme (Verbruggen \& Denys, 1995).

The high number of woody taxa that have been found and comparison with botanical studies of actual alluvial hardwood forests (e.g. Schnitzler, 1994, 1995, 1997; Wolf et al., 1997; Decocq, 2002) suggest that the results of the charcoal and seeds identifications results in a fairly complete image of the taxonomic composition of the woody vegetation on the sand ridges. Acer pseudoplatanus, Fagus sylvatica and Carpinus betulus, species that now sometimes occur on the highest elevations within alluvial hardwood forests have not been found. These trees did not reach the area before the late Holocene period however (Verbruggen et al., 1996; Maes et al., 2006).

\section{4 - WOODLAND EXPLOITATION}

\subsection{1 - Firewood Collection}

Most of the charcoal that has been recovered from the sites at Doel is considered to represent the remains of firewood that has been collected and used for heating and the preparation of food. There are no indications for other activities involving fire (e.g. firing of ceramics, tar production,...) though these cannot entirely be excluded. For prehistoric societies, it is generally assumed that firewood collection is largely based on the "principle of the least effort", especially when wood is plentiful available (Shackleton \& Prins, 1992). This means that firewood would have been collected close to the site and that all taxa were collected in proportion to their occurrence in the environment. Alternative firewood collection strategies, based on selection or avoidance of certain taxa may be expected when functional, ritual or symbolic motivations are involved however (Smart \& Hofmann, 1988; Chabal 1997; Asouti \& Austin, 2005; Dufraisse, 2008; Deforce \& Haneca, 2012). The same might be true when wood has originally been collected for another purpose and the remains are used as fuel (Kreuz, 1988). Another bias in the representativeness of the charcoal assemblage can occur when the analyzed charcoal residue is the result of short time events (Chabal, 1997; Heinz \& Thiébault, 1998; Asouti \& Austin, 2005).

Based on the pollen data from nearby sites (Janssens \& Ferguson, 1985; Minnaert \& Verbruggen, 1986; Gelorini et al., 2006; Deforce, 2011), all showing percentages of arboreal pollen above $80 \%$ for the period under consideration, it can be concluded that wood must indeed have been abundantly available. Although the studied charcoal fragments were recovered from rather small clusters, the taxonomic diversity of each analyzed sample and the similarity of the charcoal assemblages of the different clusters indicate that these charcoal fragments are probably not the result of short time activities (sensu Chabal, 1997) but are likely to result from the repeated use of these fire places and have probably been in use for a whole season of occupation. As there are also no indications for the origin for the analyzed charcoal, other than domestic fires, it is thus assumed that the observed charcoal assemblage largely 
reflects the vegetation on and directly around the sand ridge during the period of occupation.

One exception is Viscum album. The high percentages of $V$. album charcoal in some of the analyzed samples (up to $12.3 \%$ in sector $\mathrm{B}$, and up to $22.4 \%$ in sector $\mathrm{M}$ ) can most likely not be explained by its collection as firewood, even unintentionally being attached to branches of other collected taxa. As $V$. album produces only extremely small wood volumes, it is not very useful as firewood, and, as a hemi-parasite, it grows on branches of trees and shrubs, and was therefore probably hard to collect. It is therefore believed that $V$. album has deliberately been collected for another, more specific use, and that the refuse has been thrown in the fire. In combination with the large numbers of seeds of Hedera helix, these high percentages of $V$. album indicate the collection and use of both species for their use as leaf fodder to feed domestic animals during winter/early spring. This interpretation is mainly based on similar finds of $V$. album and H. helix in or associated with animal dung from early Neolithic sites in central Europe and southern Scandinavia (e.g. Rasmussen, 1993; Akeret et al., 1999; Haas, 2004; Robinson, 2007) and is elaborately discussed in Deforce et al. (2013).

The percentages for most other taxa in the charcoal assemblage might thus be fairly representative for their abundance in the vegetation on the sand ridges. Also the similarity between the charcoal assemblages from sector B and sector M might be an indication for this. Moreover, also for Swifterbant sites in the Netherlands, it is concluded from the comparison of waterlogged wood with charcoal data, that firewood collection is primarily based on availability (Casparie et al. 1977; Out, 2010b).

Another remarkable element in the charcoal spectra from the sites from Doel is the high number of light demanding taxa. Cornus sanguinea, Corylus avellana, Ligustrum vulgare, Craetagus monogyna, Prunus spinosa, Viburnum opulus and Maloideae establish only rarely in mature forest but can be abundant along forest margins and in gaps (Ellenberg, 1988). High numbers of these taxa, especially Maloideae, are also found at several other early Neolithic sites from Belgium (Salavert, 2008; Salavert et al. in press), the Netherlands (Bakels et al., 1993) and Germany (Kreuz, 1988; Jansen $\&$ Nelle, in press) and are interpreted as resulting from woodland clearances and the use of wood from hedges. At Doel however, there is no increase in light demanding taxa in the younger features, however, as is the case in many other early Neolithic sites (e.g. Marinova \& Thiébault, 2008; Salavert, 2008; Salavert et al., in press). There are also no indications for crop cultivation and therefore anthropogenic woodland disturbance might have been minimal, though vegetation opening might have been caused by other activities (e.g. Simmons \& Innes, 1987; Innes \& Blackford, 2003). The high diversity of light demanding shrubs at the sites of Doel however can most probably be explained by the nature of the natural vegetation itself at these sites, as current alluvial hardwood forests generally do show a larger abundance in both shrubs and lianas. This is explained by the unevenness in the canopy, coupled with the small size of the leaves, favoring light penetration to trunk and ground level (Schnitzler, 1994).

Apart from these charcoal identifications, there are hardly any other data that provide reliable information on the relative abundance of these light demanding taxa in the original vegetation for comparison however. Except for Corylus avellana, all occur only sporadically and with very low percentages in the off-site pollen diagrams from the region, but as these shrubs are entomophilous with poor pollen production and dispersal capacities, no conclusions can be drawn from this observation. On the other hand, rather high numbers of charred seeds and fruits of Corylus avellana, C. sanguinea and Malus sylvestris/Pyrus piraster and some of Prunus spinosa, Viburnum opulus and Crataegus monogyna have been found. As the fruits of these plants are very likely to have been collected as food (see further), these percentages also do not provide reliable information on their abundance in the original vegetation cover. Seeds from Salix sp. have not been found but these have virtually no chance to be preserved charred.

\subsection{2 - Food and other Useful Plants}

At the sites of Doel sector B and sector M, almost all identified seeds and fruits are from trees or shrubs (94.9\%). In Doel sector B, only a single carbonized cereal grain (Triticum aestivum/durum) has been found, and very little amounts of other non-woody plants (Bastiaens et al., 2005). In Doel sector M, no remains of crop plants have been found and $94.7 \%$ of the identified seeds are from trees and shrubs (Deforce et al., 2013). Almost all these identified seeds from woody plants might have been collected as food or for other use by man. Hazelnuts (Corylus avellana), acorns (Quercus sp.), crab apples (Malus sylvestris subsp. sylvestris), sloe plums (Prunus spinosa), dogwood berries (Cornus sanguinea), common hawthorn berries (Crataegus monogyna), guelder rose berries (Viburnum opulus) are also common finds at other Swifterbant sites and are, if carbonised, considered to represent waste from plant food (e.g. Bakels et al., 1993; Bakels \& Van Beurden, 2001; Out, 2008, 2010a, 2012). Seeds from Viscum album and Hederea helix are believed to represent the refuse of animal fodder (see above). Only for the seeds of T. cordata and Tilia platyphyllos anthropogenic use is less likely but only very small numbers of these taxa have been found. Though seeds and fruits from herbs might be underrepresented as these are less likely to survive the carbonisation process, these trees and shrubs seem to have formed an important component of the botanical diet at the Doel sites. Except for Viburnum opulus, which might have occurred both on wet and on dryer soil types, all these trees and shrubs must have grown on the sand ridge itself, assumed that they have not been brought in from upland sites. Moreover, Out (2012) demonstrated that also at many of the Swifterbant wetland sites from the Netherlands, dry land taxa dominate assemblages of (probably) collected plants. 


\section{5 - CONCLUSION}

The Swifterbant sites of Doel are situated on top of sand ridges which represented the only relatively permanent dry spots in a vast area of wetlands. These sand ridges supported alluvial hardwood forests which were exploited for firewood collection, the gathering of food plants and most probably also for the collection of leaf fodder. The high productivity and taxonomic diversity of this vegetation type might thus have contributed to the attractiveness of these places for settling and the many resources provided by this ecosystem might have contributed to the persistence of the broad spectrum economy of the Swifterbant culture.

\section{ACKNOWLEDGMENTS}

The authors are grateful to Daisy Van Cotthem, Nele van Gemert and Annelies Storme for help with the figures and Mona Court-Picon for help with the French abstract.

\section{REFERENCES}

AKERET Ö., HAAS J.N., LEUZINGER U. \& JACOMET S., 1999 - Plant macrofossils and pollen in goat/sheep faeces from the Neolithic lake-shore settlement Arbon Bleiche 3, Switzerland. The Holocene, 9 (2), 175-182.

ASOUTI E. \& AUSTIN P., 2005 - Reconstructing woodland vegetation and its exploitation by past societies, based on the analysis and interpretation of archaeological wood charcoal macro-remains. Environmental Archaeology, 10 (1), 1-18.

BAKELS C.C., ALKEMADE M.J. \& VERMEEREN C.E., 1993 - Botanische Untersuchungen in der Rössener Siedlung Maastricht-Randwijck. Archaeo-Physica, 13, 35-48.

BAKELS C.C. \& VAN BEURDEN L.M., 2001 - Archeobotanie. In L.P. Louwe Kooimans (ed.), Archeologie in de Betuweroute. Hardinxveld-Giessendam Polderweg. Rapportage archeologische Monumentenzorg, 83. Rijksdienst voor het Oudheidkundig Bodemonderzoek, Amersfoort, 325-378.

BASTIAENS J., DEFORCE K., KLINCK B., MEERSSCHAERT L., VERBRUGGEN C. \& VRYDAGHS L., 2005 - Palaeobotanical analyses. In P. Crombé (ed.), The last hunter-gatherer-fishermen in Sandy Flanders (NW Belgium). The Verrebroek and Doel excavation projects. Volume 1: Palaeo-environment, chronology and features. Archaeological Reports Ghent University, 3. Academia Press, Gent, 251-278.

BEHRE K.-E., 2004 - Coastal development, sea-level change and settlement history during the later Holocene in the Clay District of Lower Saxony (Niedersachsen), northern Germany. Quaternary International, 112 (1), 37-53.

BRONK RAMSEY C., 2009 - Bayesian analysis of radiocarbon dates. Radiocarbon, 51 (1), 337-360.

CARBIENER R., 1970 - Un exemple de type forestier execeptionnel pout l'Europe occidentale : la forêt du lit majeur du Rhin au niveau du fossé rhénan (Fraxino-Ulmetum Oberd. 53). Intérêt écologique et biogéographique. Comparaison à d'autres forêts thermophiles. Vegetatio, 20 (1-4), 97-148.

CASPARIE W.A., MOOK-CAMPS B., PALFENIER-VEGTER R.M., STRUYCK P.C. \& VAN ZEIST W.A., 1977 - The palaeobotany of Swifterbant. A preliminary report. Helinium, 17, 28-55.

CHABAL L., 1997 - Forêts et sociétés en Languedoc (Néolithique final, Antiquité tardive). L'anthracologie, méthode et paléoécologie. Document d'Archéologie Française, 63. Éditions de la Maison des Sciences de l'Homme, Paris, 189 p.

CROMBÉ P. (ed.), 2005 - The last hunter-gatherer-fishermen in Sandy Flanders (NW Belgium). The Verrebroek and Doel excavation projects. Volume 1: Palaeo-environment, chronology and features. Archaeological Reports Ghent University 3. Academia Press, Ghent, 334 p.

CROMBÉ P., BATS M., WUYTS F. \& VAN ROEYEN J.-P., 2004 - Een derde vindplaats van de Swifterbantcultuur in het
Deurganckdok te Doel (Beveren, Oost-Vlaanderen, België). Notae Praehistoricae, 24, 105-107.

CROMBÉ P., SERGANT J. \& PERDAEN Y., 2009 - The neolithisation of the Belgian lowlands: new evidence from the Scheldt Valley. In S.B. McCartan, R. Schulting, G. Warren, \& P. Woodman (eds.), Mesolithic Horizons. Papers presented at the Seventh International Conference on the Mesolithic in Europe, Belfast 2005. Oxbow books, Oxford, 564-569.

CROMBÉ P., BOUDIN M. \& VAN STRYDONCK M., 2011 - Swifterbant pottery in the Scheldt basin and the emergence of the earliest indigenous pottery in the sandy lowlands of Belgium. In S. Hartz, F. Lüth, \& T. Terberger (eds.), Early Pottery in the Baltic - Dating, Origin and Social Context. Bericht der Römisch-Germanischen Kommission, 89, 465-483.

DECOCQ G., 2002 - Patters of plant species and community diversity at different organization levels in a forested riparian landscape. Journal of Vegetation Science, 13 (1), 91-106.

DEFORCE K., 2011 - Middle and late Holocene vegetation and landscape evolution of the Scheldt estuary. A palynological study of a peat deposit from Doel (N-Belgium). Geologica Belgica, 14 (3-4), 277-288.

DEFORCE K. \& HANECA K., 2012 - Ashes to ashes. Fuelwood selection in Roman cremation rituals in northern Gaul. Journal of Archaeological Science, 39 (5), 1338-1348.

DEFORCE K., BASTIAENS J., VAN NEER W., ERVYNCK A., LENTACKER A., SERGANT J. \& CROMBÉ P., 2013 - Wood charcoal and seeds as indicators for animal husbandry in a wetland site during the late mesolithic-early neolithic transition period (Swifterbant culture, ca. 4600-4000 BC) in NW Belgium. Vegetation History and Archaeobotany, 22 (1), 51-60.

DEICHMÜLLER J., 1965 - Die neolitische Moorsiedlung Hüde I am Dümmer, Kreis Grafschaft Diepholz. Neue Ausgrabungen und Forschungen in Niedersachsen, 2, 1-18.

DRESSCHER S. \& RAEMAEKERS D.C.M., 2001 - Oude geulen op nieuwe kaarten. Het krekensysteem bij Swifterbant. Paleo-Aktueel, 21, 31-38.

DUFRAISSE A., 2008 - Firewood management and woodland exploitation during the late Neolithic at Lac de Chalain (Jura, France). Vegetation History and Archaeobotany, 17 (2), 199-210.

ELLENBERG H., 1988 - Vegetation ecology of Central Europe Cambridge University Press, Cambridge, 731 p.

GELORINI V., VERLEYEN E., VERBRUGGEN C. \& MEERSCHAERT L., 2006 - Paleo-ecologisch onderzoek van een Holocene sequentie uit het Deurganckdock te Doel (Wase Scheldepolders, Noord-België). Belgeo, 3, 243-264.

GROSSER D., 2003 - Die Hölzer Mitteleuropas. Ein mikrophotographischer Lehratlas, reprint of the $1^{\text {st }}$ edition from 1977. Verlag Dr. Kessel, Remagen, 217 p.

GRUBB P.J., 1987 - Global trends in species richness in vegetation: a view from the northern hemisphere. In G.H.R. Gee \& P.S. Giller (eds.), The organization of communities, Past and Present. Blackwell Scientific Publications, Oxford \& Boston, 99-118.

HAAS J.N., 2004 - Mikroskopische Analyse von Schaf-/Ziegenkoprolieten. Archäologie im Thurgau, 12, 351-357.

HEINZ C. \& THIÉBAULT S., 1998 - Characterization and palaeoecological significance of archaeological charcoal assemblages during Late and Post-Glacial phases in southern France. Quaternary Research, 50 (1), 56-68.

INNES J.B. \& BLACKFORD J.J., 2003 - The ecology of Late Mesolithic woodland disturbances: model testing with fungal spore assemblage data. Journal of Archaeological Science, 30 (2), 185-194.

JANSEN D. \& NELLE O., in press - The Neolithic woodland Archaeoanthracology of six Funnel Beaker sites in the lowlands of Germany, Journal of Archaeological Science. doi: 10.1016/j. jas.2012.10.024.

JANSSENS W. \& FERGUSON D.K., 1985 - The palaeoecology of the Holocene sediments at Kallo, Northern Belgium. Review of Palaeobotany and Palynology, 46 (1-2), 81-95.

KLINCK B., 2005 - Charcoal analysis. In P. Crombé (ed.), The last hunter-gatherer-fishermen in Sandy Flanders (NW Belgium). The Verrebroek and Doel excavation projects. Volume 1: Palaeo-environment, chronology and features. Archaeological Reports Ghent University, 3. Academia Press, Gent, 267-271.

KREUZ A., 1988 - Holzkohle-Funde der ältestbandkeramischen Siedlung Friedberg-Bruchenbrücken: Anzeiger für BrennholzAuswahl und lebende Hecken? In H. Küster (ed.), Der prähistorische Mensch und seine Umwelt. Konrad Theiss Verlag, Stuttgart, 139-153.

KUIJPER W.J., 2006 - Flora en fauna in en rond een Scheldegeul bij Kallo op het einde van het Atlanticum (Beveren, prov. Oost-Vlaanderen). Relicta, 1, 29-48. 
LOUWE KOOIJMANS L.P., 1987 - Neolithic settlement and subsistence in the wetlands of the Rhine/Meuse Delta of the Netherlands. In J.M. Coles \& A.J. Lawson (eds.), European wetlands in prehistory. Clarendon Press, Oxford, 227-251.

LOUWE KOOIJMANS L.P., 1993 - Wetland exploitation and upland relations of prehistoric communities in the Netherlands. In J. Gardiner (ed.), Flatlands and wetlands: current themes in East Anglian archaeology. East Anglian Archaeology Report, 50. Scole Archaeological Committee for East Anglia, Norwich, 71-116.

LOUWE KOOIJMANS L.P., 2007a - The gradual transition to farming in the Lower Rhine Basin. In A. Whittle \& V. Cummings (eds.), Going Over: the Mesolithic-Neolithic Transition in NorthWest Europe. Oxford University Press, Oxford, 287-309.

LOUWE KOOIJMANS L.P., 2007b - Van Hardinxveld naar Schipluiden. Van Jager tot boer. In R. Jansen \& L.P. Louwe Kooijmans (eds.), From contract to science. Ten years of archaeological investigations by Archol BV, 1997-2007. Archol, Leiden, 152-166.

LOUWE KOOIJMANS L.P., 2009 - The agency factor in the process of Neolithisation - a Dutch case study. Journal of Archaeology in the Low Countries, 1 (1), 27-54.

LOUWAGIE G. \& LANGOHR R., 2005 - Pedo-lithostratigraphical analyses. In P. Crombé (ed.), The last hunter-gatherer-fishermen in Sandy Flanders (NW Belgium). The Verrebroek and Doel excavation projects. Volume 1: Palaeo-environment, chronology and features. Archaeological Reports Ghent University, 3. Academia Press, Gent, 27-107.

MAES B., BASTIAENS J., BRINKKEMPER O., DEFORCE K., RÖVEKAMP C., VAN DEN BREMT P. \& ZWAENEPOEL A., 2006 - Inheemse bomen en struiken in Nederland en Vlaanderen. Boom, Amsterdam, $376 \mathrm{p}$.

MARINOVA E. \& THIÉBAULT S., 2008 - Anthracological analysis from Kovacevo, southwest Bulgaria: woodland vegetation and its use during the earliest stages of the European Neolithic. Vegetation History and Archaeobotany, 17 (2), 223-231.

MINNAERT G. \& VERBRUGGEN C., 1986 - Palynologisch onderzoek van een veenprofiel uit het Doeldok te Doel. Bijdragen van de Archeologische Dienst Waasland, 1, 201-208.

MOL J., 2003 - Landscape evolution and site formation of two mesolithic sites in the Lower Rhine-Meuse dela (Hardinxveld, The Netherlands). In A.J. Howard, M.G. Macklin \& D.G. Passmore (eds.), Alluvial Archaeology in Europe. Balkema Publishers, Lisse, 147-161.

OUT W.A., 2008 - Neolithisation at the site Brandwijk-Kerkhof, the Netherlands: natural vegetation, human impact and plant food subsistence. Vegetation History and Archaeobotany, 17 (1), 25-39.

OUT W.A., 2010a - Integrated archaeobotanical analysis: Human impact at the Dutch Neolithic wetland site the Hazendonk. Journal of Archaeological Science, 37 (7), 1521-1531.

OUT W.A., 2010b - Firewood collection strategies at Dutch wetland sites in the process of Neolithisation. The Holocene, 20 (2), 191-204.

OUT W.A., 2012 - What's in a hearth? Seeds and fruits from the Neolithic fishing and fowling camp at Bergschenhoek, The Netherlands, in a wider context. Vegetation History and Archaeobotany, 21 (3), 201-214.

PONS L.J., 1992 - Holocene peat formation in the lower parts of the Netherlands. In J.T.A. Verhoeven (ed.), Fens and Bogs in the Netherlands: Vegetation, History, Nutrient Dynamics and Conservation. Kluwer Academic Publishers, Dordrecht, 7-79.

RAEMAEKERS D.C.M. \& DE ROEVER J.P., 2010 - The Swifterbant pottery tradition (5000-3400 BC). Matters of fact and matters of interest. In B. Van Montfort, L.P. Louwe Kooijmans, L. Amkreutz $\&$ L. Verhart (eds.), Pots, Farmers and Foragers. Pottery traditions and social interaction in the earliest Neolithic of the lower Rhine area. Archaeological Studies Leiden University, 20, Leiden University Press, Leiden, 135-149.

RASMUSSEN P., 1993 - Analysis of Goat/Sheep faeces from Egolzwil 3, Switzerland: evidence for branch and twig foddering of livestock in the Neolithic. Journal of Archaeological Science, 20 (5), 479-502.

REIMER P.J., BAILLIE M.G.L., BARD E., BAYLISS A., BECK J.W., BLACKWELL P.G., BRONK-RAMSEY C., BUCK C.E., BURR G.S., EDWARDS R.L., FRIEDRICH M., GROOTES P.M., GUILDERSON T.P., HAJDAS I., HEATON T.J., HOGG A.G., HUGHEN K.A., KAISER K.F., KROMER B., MCCORMAC F.G., MANNING S.W., REIMER R.W., RICHARDS D.A., SOUTHON J.R., TALAMO S., TURNEY C.S.M., VAN DER PLICHT J. \& WEYHENMEYER C.E., 2009 - Intcal09 and Marine09 radiocarbon age calibration curves, 0-50,000 years cal BP. Radiocarbon, 51 (4), 1111-1150.

ROBINSON D.E., 2007 - Exploitation of plant resources in the Mesolithic and Neolithic of southern Scandinavia: from gathering to harvesting. In S. Colledge \& J. Conolly (eds.), The origins and sread of Domestic Plants in Southwest Asia and Europe. Left Coast Press, Walnut Creek, 359-374.

SALAVERT A., 2008 - Analyse anthracologique du site rubané de Remicourt «En Bia Flo II» (Hesbaye, Belgique) : premiers résultats. In L. Burnez-Lanotte, M. Ilett \& P. Allard (eds.), Fin des traditions danubiennes dans le Néolithique du Bassin parisien et de la Belgique (5100-4700 av. J.-C.). Mémoire de la Société Préhistorique Française, 44. Société Préhistorique Française, Paris \& Presses Universitaires de Namur, Namur, 317-326.

SALAVERT A., BOSQUET D. \& DAMBLON F., in press - Natural woodland composition and vegetation dynamic during the Linearbandkeramik in north-western Europe (central Belgium, 5200500 BC). Journal of Archaeological Science. doi: 10.1016/j. jas.2012.10.017.

SCHEPERS M., SCHEEPENS J.F., CAPPERS R.T.J., VAN TONGEREN O.F.R., RAEMAEKERS D.C.M. \& BEKKER R.M., 2013 - An objective method based on assemblages of subfossil plant macro-remains to reconstruct past natural vegetation: a case study at Swifterbant, The Netherlands. Vegetation History and Archaeobotany, 22 (3), 243-255.

SCHNITZLER A., 1994 - European alluvial hardwood forests of large floodplains. Journal of Biogeography, 21 (6), 605-623.

SCHNITZLER A., 1995 - Successional status of trees in gallery forest along the river Rhine. Journal of Vegetation Science, 6 (4), 479-486.

SCHNITZLER A., 1997 - River dynamics as a forest process: interaction between fluvial systems and alluvial forests in large European river plains. The Botanical Review, 63 (1), 40-64.

SCHOCH W., HELLER I., SCHWEINGRUBER F.H. \& KIENAST F., 2004 - Wood anatomy of central European Species. Online version: www.woodanatomy.ch

SCHWEINGRUBER F.H., 1990 - Microscopic Wood Anatomy: structural variability of stems and twigs in recent and subfossil woods from Central Europe. $3^{\text {rd }}$ edition, Eidgenössische Forschungsanstalt WSL, Birmensdorf, $226 \mathrm{p}$.

SHACKLETON C.M. \& PRINS F., 1992 - Charcoal analysis and the "Principle of the least effort" - A conceptual model. Journal of Archaeological Science, 19 (6), 631-637.

SIMMONS I.G. \& INNES J.B., 1987 - Mid-holocene adaptations and later Mesolithic forest disturbance in Northern England. Journal of Archaeological Science, 14 (4), 385-394.

SMART T.L. \& HOFMANN E.S., 1988 - Environmental interpretation of archaeological charcoal. In C.A. Hastorf \& V.S. Popper (eds.), Current Paleoethnobotany. University of Chicago Press, Chicago, 165-205.

VAN DER WIEL A.M., 1982 - A palaeoecological study of a section from the foot of the Hazendonk (Zuid-Holland, The Netherlands), based on the analysis of pollen, spores and macroscopic plant remains. Review of Palaeobotany and Palynology, 38 (1-2), 35-90.

VAN DER WOUDE J.D., 1983 - Holocene palaeoenvironmental evolution of a perimarine fluviatile area. Geology and palaeobotany of the area surrounding the archaeological excavation at the Hazendonk river dune (Western Netherlands). Hazendonk paper I. Analecta Praehistorica Leidensia, 16, 1-124.

VAN NEER W., ERVYNCK A. \& LENTACKER A., 2005 - Archaeozoological analyses. In P. Crombé (ed.), The last hunter-gathererfishermen in Sandy Flanders (NW Belgium). The Verrebroek and Doel excavation projects. Volume 1: Palaeo-environment, chronology and features. Archaeological Reports Ghent University, 3. Academia Press, Gent, 279-294.

VAN NEER W., ERVYNCK A., LENTACKER A., BASTIAENS J., DEFORCE K., THIEREN E., SERGANT J. \& CROMBÉ PH., 2013 - Hunting, gathering, fishing and herding: animal exploitation in Sandy Flanders (NW Belgium) during the second half of the fifth millennium BC. Environmental Archaeology, 18 (2), 87-101.

VAN RIJN P. \& KOOISTRA L.I., 2001 - Hout en houtskool: het gebruik van hout als constructiemateriaal en brandstof. In J.W.H. Hogestijn \& J.H.M. Peeters (eds.), De mesolithische en vroeg-neolithische vindplaats Hoge Vaart-A27 (Flevoland). Berichten van de Rijksdienst voor het Oudheidkundig Bodemonderzoek, 15. Rijksdienst voor het Oudheidkundig Bodemonderzoek, Amersfoort, $1-103$.

VAN STRYDONCK M. \& CROMBÉ PH., 2005 - Radiocarbon dating. In P. Crombé (ed.), The last hunter-gatherer-fishermen in Sandy Flanders (NW Belgium). The Verrebroek and Doel excavation projects. Volume 1: Palaeo-environment, chronology and features. Archaeological Reports Ghent University, 3. Academia Press, Gent, 180-212.

VERBRUGGEN C. \& DENYS L., 1995 - Early tidal influence on the Lower Schelde, Belgium. Aardkundige Mededelingen, 6, 167-169.

VERBRUGGEN C., DENYS L. \& KIDEN P., 1996 - Belgium. In B.E. Berglund, H.J.B. Birks, M. Ralska-Jasiewiczowa \& H.E. Wright 
(eds.), Palaeoecological Events During the Last 15.000 Years: Regional Syntheses of Palaeoecological Studies of Lakes and Mires in Europe. John Wiley \& Sons, Chichester, 553-574.

VOS P.C. \& VAN HEERINGEN R.M., 1997 - Holocene geology and occupation history of the province of Zeeland (SW Netherlands). Mededelingen Nederlands Instituut voor Toegepaste Geowetenschappen TNO, 59, 5-109.
VOS P., BAZELMANS J., WEERTS H. \& VAN DER MEULEN M. 2011 - Atlas van Nederland in het Holoceen. Uitgeverij Bert Bakker, Amsterdam, $94 \mathrm{p}$.

WOLF R.J.A.M., VRIELINK J.G. \& DE WAAL R., 1997 - Riverine woodlands in The Netherlands. Global Ecology and Biogeography Letters, 6 (3-4), 287-295. 